Head transverse, very little broader than the thorax, the occiput emarginate at middle, the cheeks margined; face below the antennae, prominently convex, shining, with sparse whitish hairs; clypeus separated, subconvex; mandibles piceous; palpi brown, the maxillaries very long. Antennae I4-jointed, longer than the body, setaceous, brown, the scape and pedicel yellowish; scape not quite twice as long as the pedicel; flagellum slender, cylindrical, the joints very slightly subequal, after the $3^{\text {rd about }} 4$ times as long as thick. Metanotum with a median sulcus bounded by carinae. Wings hyaline, the stigma and nervures pale brown.

Hab.-Washington, D. C.

Type in National museum.

The single $\hat{\sigma}$ specimen was reared May 3, I88I, from Grapholitha prunivora Walsh.
5. M. pallida sp. n. \&.-Length $2 \mathrm{~mm}$. Brownish-yellow, minutely closely punctulate. Antennae I4-jointed, fuscous toward tips, flagellar joints $I$ and 2 about equal, as long as the two last joints united, joints 3 and 4 about the length of the 2 nd, those beyond gradually become shorter, subequal. Eyes brown, subpubescent. Mesopleurae smooth. Metanotum with a distinct median carina. Wings hyaline, the stigma and nervures brownish yellow. Abdomen oval, as long as the thorax, the first segment with a narrow linear shield, the membranaceous margins broad; ovipositor as long as the basal tarsal joint in hind legs. All tarsi more or less fuscous.

Hab.-Jacksonville, Florida.

Type in Coll. Ashmead.

The large size and pale color readily distinguish the species.

\title{
NOTES ON THE LARVAL STAGES OF ARCTIA BLAKEI Grote.
}

\author{
BY HARRISON G. DYAR, BOSTON, MASS.
}

Euprepia (Cymbalophora) blakei Grote. I863-Grote, Proc. ent. soc. Phil., iii, 523. Arctia.

1874-Stretch, Zyg. Bomb. N. A., 224. I $892-$ Kirby, Cat. Lep. Het., i, 267. Apantesis.

superba Stretch.

I874-Stretch, Zyg. Bomb. N. A., 227.

geneura Strecker.

I 878-Strecker, Proc. Dav. acad. sci., ii, 270.

I884-French, Papilio, iv, I 58.

1889-French, Can. ent., xxi, 162 .

incorrupta $\mathrm{Hy}$. Edwards.

I881-Hy. Edw., Papilio, i, 38 .

shastaensis Behrens.

1889-French, Can. ent., pp. 35 and 162.

var. NEVADENSIS Grote and Robinson.

I 866-Grt. and Robs., Proc. ent. soc. Phil., vi, i Arctia.
I886-Grote, Can. ent., xviii, Io9.

I892-Kirby, Cat. lep. Het., i, 268. Apantesis.

behrii Stretch.

I872-Stretch, Zyg. Bomb., N. A., 75.

var. SUlPHURICA Neumoegen.

1885-Neum., Ent. amer., i, 93.

elongata Stretch.

I885-Stretch, Ent. Amer., i, IO5.

I892-Kirby, Cat. lep. Het. i, 270.

ochracea $\|$ Neum.

I883-Neum., Papilio, iii, I5r.

In Kirby's catalogue the American species, formerly referred to Arctia, are distributed irregularly under three generic names. As the species do not seem to be separable generically, I adopt the oldest name for the genus, viz. Euprepia Ochs. (1810), under which name are found $E$. pudica Esp. and $E$. fasciata Esp. Arctia Schrank is restricted 
to $A$. villica Linn. and $A$. bieti Oberthur, while the species formerly referred to $\mathrm{Eu}$ prepia, viz. $E$. caja Linn. and allies, are referred to Hypercompa Hübn. (Tentamen, I805?) which is the same as Zoote Hübn. (Verz., I822?). The generic names of the catalogue may be used as subgeneric or group names; but the species must be better assorted than has been done. Apantesis Walker must be restricted to $A$. nais and decorata; Callarctia Packard will stand for the species with the veins lined with pale scales, while the name Cymbalophora Ramb. can be used for the American allies of $E$. pudica Esper, of which the present species, E. blakei Grt., is one.

The following notes were made on the larvae :-

$E g g$-Sub-conoidal, flat at base, perfectly smooth even under the microscope; shining pale yellow; diameter $0.8 \mathrm{~mm}$. The shell is transparent, so that the little larva can be plainly seen within. The eggs are laid unattached, so that they readily roll about.

First stage.-Head slightly bilobed, black and shining, paler around the mouth; width $0.4 \mathrm{~mm}$. Body normal, whitish, the cervical shield black; hairs evident, single from the concolorous warts, black. Later the warts become black, large and distinct.

Second stage.-Head bilobed, shining light brown, blackish at vertices of lobes and around mouth; eyes black; width $0.6 \mathrm{~mm}$. Body very pale brown, with an obscure, slightly whitish, dorsal line; warts large with many long, spreading, blackish hairs; cervical shield and warts black. There is the appearance of a subdorsal line, caused by the contrast of the pale ground color with the warts of rows 2 and 3.

Third stage.-Head bilobed, shining pale brown, black in front centrally and on vertex; ocelli large, black; width $0.8 \mathrm{~mm}$. Body brown, with a rather broad whitish dorsal line; warts very large, black, with abundant long, spreading, black hairs, especially long posteriorly and supplemented by a few very long white hairs, arising from joints 12 and 13. Cervical shield shining blackish brown; thoracic feet black. The larvae are very active in running to hide beneath leaves, etc., if disturbed.

Fourth stage.-As before; width of head I.I $\mathrm{mm}$. The dorsal line is straight and even, well defined, nearly white. The body is a little mottled on the sides, dark, nearly black on the back.

Fifth stage.-Width of head $\mathrm{I} .5 \mathrm{~mm}$. Body, warts and hair all black except a narrow and rather faint reddish dorsal line, broken in the segmental incisures. Hair bristly, stiff and barbed, of irregular length. The body is pale ventrally and in the incisures; thoracic feet black, the abdominal ones pale. A few very long white hairs as before.

Sixth stage.*-Head shining pale brown, black all over the vertices of the lobes and in front on each side of the central suture and around the ocelli; antennae and mouth pale brown; width $1.75 \mathrm{~mm}$. Body black above, blackish brown below, mottled with paler, with an obscure reddish brown dorsal band; warts deep black, tuberculate; hair short, but dense, bristly and barbed, deep black except from wart 6 where it is whitish. A few (about four) very long white hairs arising from joints $\mathrm{I} 2$ and $\mathrm{I} 3$, directed posteriorly. Later the body becomes entirely deep black above with no dorsal line; the subventral hair is reddish.

Eggs received from $\mathrm{Mr}$. J. B. Lembert, Yosemite, California.

As the accurate determination of species of Euprepia is difficult and attended with chances of error, I append a description of the moth from which these eggs were obtained.

\footnotetext{
*Not the normal sixth stage, as the width of head should have been $2.2 \mathrm{~mm}$. The larvae were bred under disadvantageous circumstances, being carried from Portland, Or. to Plattsburgh, N. Y., where they finally died from the effects of the hot weather and confinement. The stage above described is an interpolated one and not the normal last stage. The species probably has but six stages naturally.
} 
ㅇ. Head and thorax above yellowish salmon color with the usual black marks; abdomen deep ocher yellow with a dorsal and lateral row of confluent black spots; below, the thorax, abdomen and legs are entirely black. Fore wings deep black with salmon colored bands, each narrowly bordered with yellowish on both sides. Basal half line absent, represented on one wing by a few scales on the costa; trans.-ant. line reaching from costa to internal margin, rather narrow, dilated at both ends; median band reaching from costa to just below the longitudinal submedian band, ending in a point; trans.-post. line slightly angulated, reaching only to the submedian band; terminal angular band (W-mark) normal, joining the trans.-post. band at about its middle; fringe and internal margin narrowly salmon color. Hind wings scarlet ("flame scarlet," Ridgway, plate vii, fig. 14) with a narrow uneven outer black border, obsolete before internal angle; three submarginal rounded-triangular spots, the last one at anal angle; two discal elongate spots, the inner one much elongate and attaining the costa, the outer, small; a large spot on the middle of abdominal margin and a small one at base. All the black marks narrowly bordered with yellowish. Fringe narrowly yellowish salmon. Below, the colored parts of both wings are orange (Ridgway, Pl. vi, f. 3) with the black parts as above. Expanse $42 \mathrm{~mm}$. The moth here described differs from all those referred to in the synonymy given above in the absence of the basal half line, and I propose for it the varietal name perpicta.

The character, though slight, is usually of such diagnostic value in the case of $E$. blake $i$ that its absence in this form seems to warrant the different designation. Prof. French has described some moths of this form as Arctia geneura Strk. (Can. ent., xxi, I62).

Entomological Notes.-Miall and Hammond have just printed a paper in the Transactions of the Linnean society of London on the development of the head in Chironomus, which will be found interesting from its representing a type intermediate between the apparently widely different types of Corethra and Musca, hitherto the best known. A great part of the head of the imago arises from paired invaginations extending far into the larval thorax.

A feast of Chionobas is offered in the new Part of Edward's Butterflies of North America, for it is devoted entirely to four species of that genus, of which the transformations of two, C.jutta and C. brucei, are described in detail and figured profusely with exquisite skill, admirably bringing out their distinctive features. Considering the home of these insects, one cannot too strongly commend the perseverance which has culminated in such a series of plates as these. The text, too, is full and interesting, indicating curious I to the printer. 

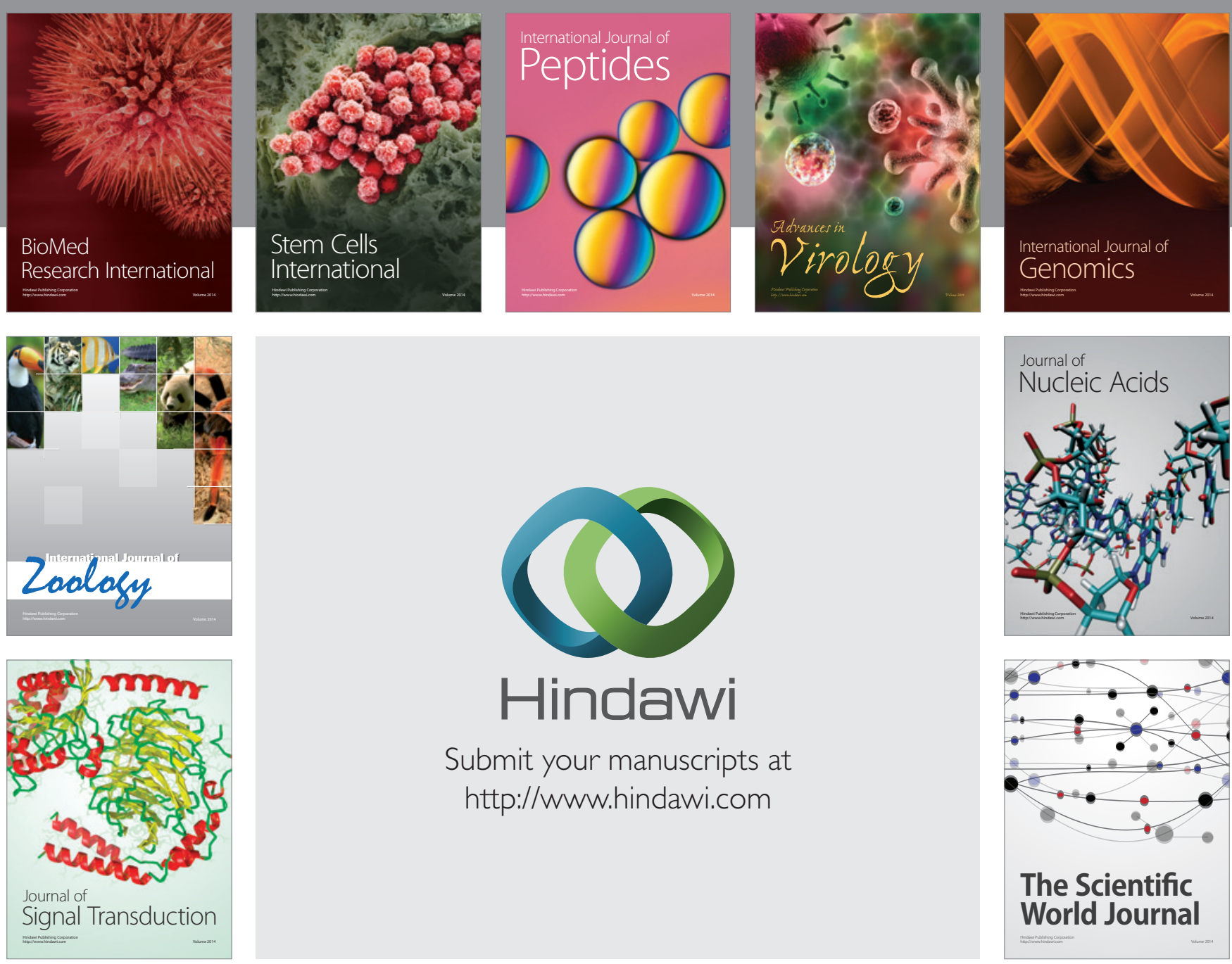

Submit your manuscripts at

http://www.hindawi.com
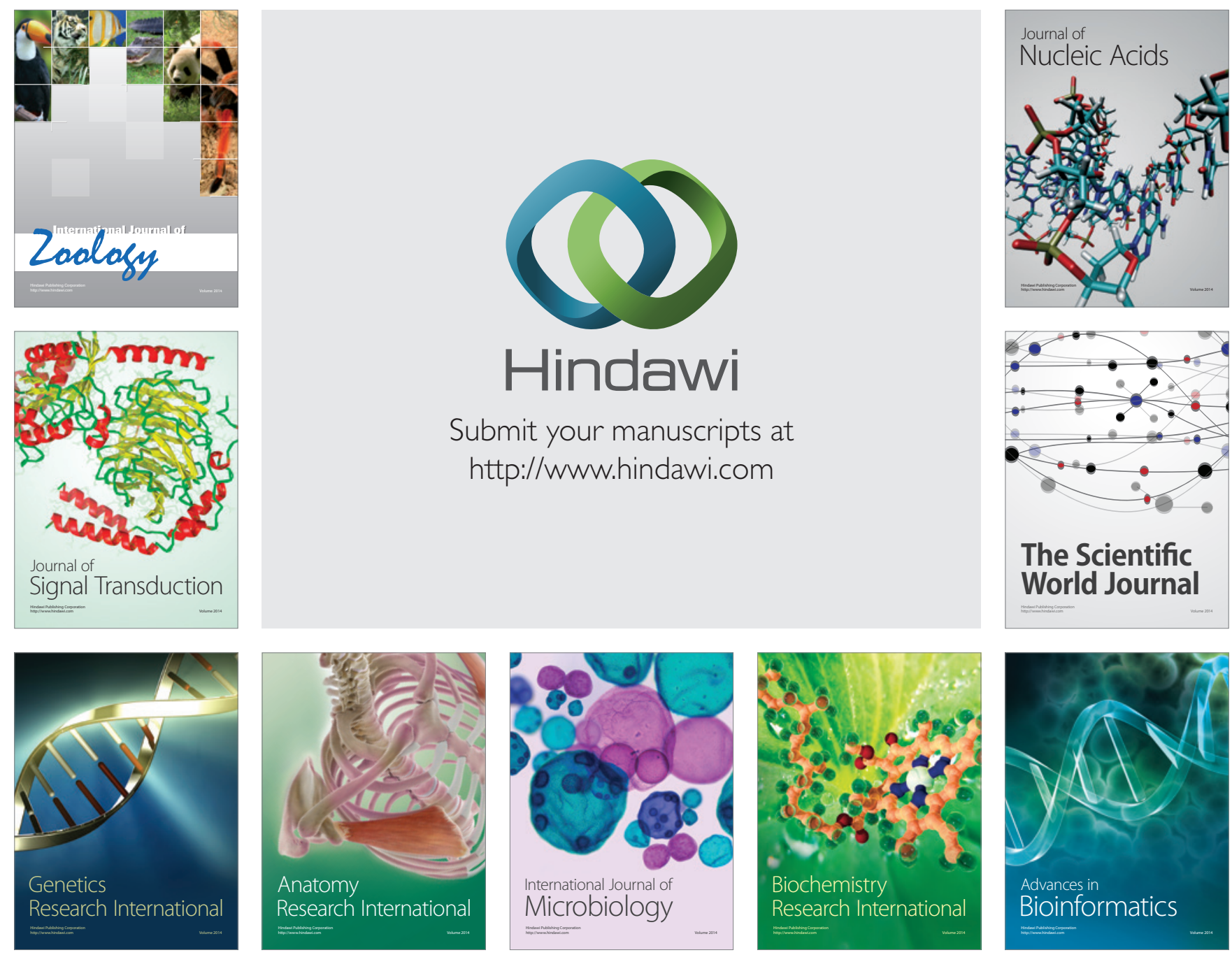

The Scientific World Journal
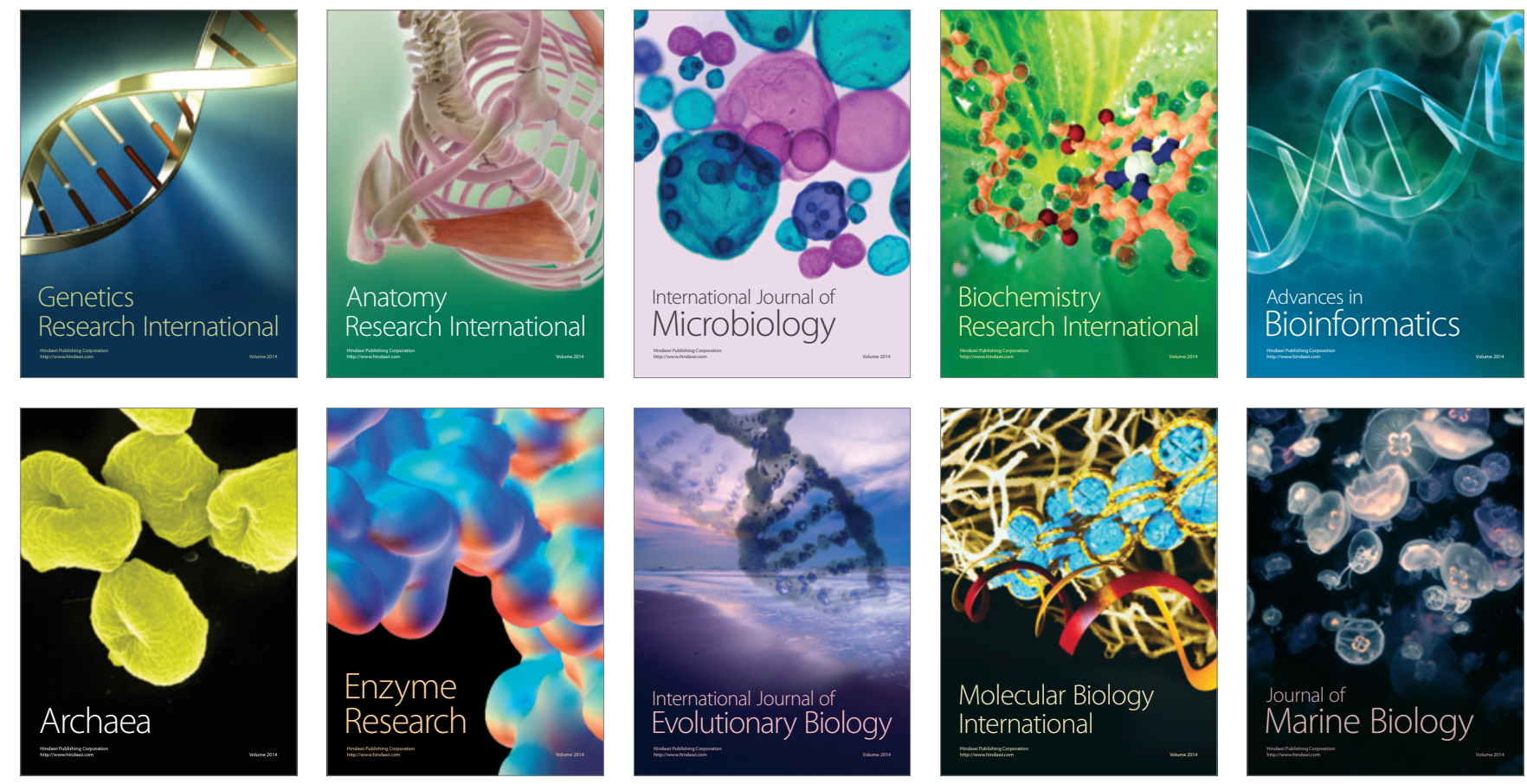